\title{
Enhancing English Academic Writing Ability Using Film and Streaming Project
}

\author{
Euis Meinawati \\ \{euis.eum@bsi.ac.id
}

Akademik Bahasa Asing BSI Jakarta, Indonesia

\begin{abstract}
The aim of the study is to find the effectiveness of film and streaming project to enhance English academic writing ability and how the students' perception in the used film in the classroom. The method in this study was an exploratory mixed method. Techniques of collecting data are documentation and questionnaire. The total number of the sample was 40 students from one of the classes. The data collected using documentation taken from students' result test of English academic writing. The English academic writing was analyzed based on the Checklist Rubric from Brown and Barley. To measure the validity of the questionnaire, the writer used the Pearson Product Moment. While to measure reliability used Alpha Cronbach. The result showed that was $78 \%$ of the students were able to write a good academic writing. From the questionnaire, it was found that $48 \%$ of the students answer "strongly agree". It means that the students' perception toward film and streaming project was very strong. They were interested to learn writing through film and streaming project and give a positive context in learning. The result of the study that the $t-$ test result is t-stat (8.89) $>\mathrm{t}$-table (2.02),. It means that there is a significant difference was found in English academic writing in favour of the students who studied academic writing before and after the use of the film and streaming project.
\end{abstract}

Keywords: Academic Writing, English, Film and Streaming

\section{Introduction}

Technology is very useful for nowadays to support English learning. It can be media of learning to make have fun learning. Especially in writing learning because, of the four skills, writing is the most difficult language skill for the learner because it is complex and requiring mastery not only grammatical and rhetorical devices but also of the conceptual and judgmental element. [1] This statement is also strengthened by Harmer as follows, writing is a comprehensive ability involving grammar, vocabulary, conception rhetoric and other elements; it has everything to do with listening, speaking and reading. Therefore, writing should by no means be restricted to writing courses or composition classes. It must be integrated with all the other language courses. [2] It means that students need knowledge and comprehension of information. But, the English academic writing class in ABA BSI Jakarta has a disadvantage. Students' ability is still low and they are not able to relate their knowledge to the theme.

Based on the result of observation in English academic writing class, some problem of academic writing are; a) the student cannot write the final paper very good because there are still mistake in structure and meaning to relate one paragraph to the other paragraph. b) There are failed score in essay writing. c) The student has low motivation to learning and has less reference to the source. d) Many lectures used a conventional approach that made the student 
bored in writing learning. As we know that in this era, student-centered is very important to make them improved their learning. Then, they can learn from their context. e) There is still a student that cannot make a thesis statement. f) The lecture and student do not use multimedia in the class. And the students cannot use their imagination. g) the students lacked vocabulary. From this condition, the students sometimes felt bored when they wrote and stuck off the words or sentences.

Based on that condition, in order to avoid the boredom of doing English academic writing assignment, the lecturer has to use technology or multimedia of learning in her class. Like as Bradbury has studied the aching writing in the context of National Digital Literacy Narrative. This study talks technology in the writing classroom. [3] It is the same with Bonsignori research about using films and TV series for ESP teaching. [4] The lecturer can make the creative strategy of learning like as film and streaming project etc. Today, film and streaming project are naturally part of young people's lives. Young people between 15-24 are the most active media consumers. They spend on average about ten hours each day using the internet, watching TV, watching the film, playing video games, reading the newspaper and listening to the radio, etc. Now, more than $50 \%$ of young people aged 9-24 state that they used the internet or social media to find everything and doing communication. Television can give the gap between teaching and learning informal language through subtitle. [5]

Technology can be one of the ways to create a real and enjoyable atmosphere for young language learners when it is used correctly and effectively. Technology lets young language learners gain language skills outside the classroom when they interact actively. Many types of research claim that children can improve their language and cultural awareness by using technology in different social and cultural contexts and language awareness can be faster through intercultural communication. [6] Thus, it is important for the lecture and the people who work with children to be aware of the role of media and popular culture in young people's lives. It is a challenge to have an open and flexible approach to film, TV, and other media. The lecture has to considered students' experience in large perspective. The possibilities of using the project as a strategy for teaching are immense. It is, for example, possible to watch a movie or film with subtitles in English or find an interesting video clip within a second or the students can make a short film project about their life. It can build students' interest in English learning. In the book Second Language Classroom, Chaudron points out that "the classroom-oriented research in the choice of descriptors and task and activity types is lacking. It is necessary to continue to look at how teaching methods and teaching material change as technology evolves."[7]

From that describing, this study will use film and streaming project that are studied in relation to learning English academic writing at ABA BSI Jakarta. My personal experience shows that films are sometimes regarded as valuable teaching material and at other times only used for amusement or as a time-filler. The problem of this study is to find (1) how the students' perception in the used film project in the classroom; and (2) how is the result of improving students' English academic writing ability?

\section{Literature Review}

\subsection{Academic paragraph writing}

Writing as a social and cultural phenomenon. Hamp - Lyons and Kroll, writing is 'an act that takes place within a context, that accomplishes a particular purpose, and that is appropriately shaped for its intended audience.' Hayes in Weigle states “(Writing) is also social 
because it is a social artefact and is carried out in a social setting. What we write, how we write, and who we write to is shaped by social convention and by our history of social interaction... The genre in which we write was invented by other writers and the phases we write often reflect phrases earlier writers have written.'[8] Weigle that writing as a cognitive activity. A good deal of literature has looked at the process writing, most frequently by using retrospective interviews or think-aloud protocols. Silvi in Weigle, in review of differences between first and second language writing found that writing in a second language tends to be 'more constrained, more difficult, and less effective' than writing in a first language : second language writers plan less, revise for contentless, and write less fluently and accurately than first - language writers.

According to Nation, writing is an activity that can usefully be prepared for my work in the other skills of listening, speaking and reading. This preparation can make it possible for words that have been used receptively to come into productive use. From this statement that writing is one of skill in a language that supports the other skill. Each learns the writing which will get the other knowledge to improve their English language. [9] Brown, a half a century ago, writing teachers were mostly concerned with the final product of writing: the essay, the report, the story, and what that product should "look" like. [10]

A different opinion from Sokolik in Linse, writing is a combination of process and product. The process refers to the act of gathering ideas and working with them until they are presented in a manner that is polished and comprehensible to readers. Olson stated that the concept that writing is a process is very useful to young writers. [11] From the explanation above that writing is a process to get the product which is talking about social and cultural. The writing is prepared to support the other skill like speaking, listening, and reading. For the second language, writing has a relationship with literature.

Smith and Heaton in line with Brown and Barley in Brown that there are five components to construct writing; (1) organization (introduction, body and conclusion), (2) logical development of ideas, (3) grammar, (4) punctuation, spelling, and mechanics, and (5) styles and quality of expression. [12] While according to Heaton, there are five components in the assessment of writing; language use, mechanical skill, treatment of content, stylistic, and judgment skills. McNamara in Weigle notes, the scale that is used in assessing performance tasks such as writing test represents, implicitly or explicitly, the theoretical basis upon which the test is founded; that is, it embodies the test (or scale) developer's notion of what skills or abilities are being measured by the test. In the composition literature, three main types of rating scales are discussed: the primary trait scale, holistic scales, and analytic scales.

The concluded that academic writing has a relationship with cultural context and cognitive activity. When each one writes using their context experience. Of course, it has the role of systematic writing. It constructs with some components like as an organization, logical development ideas, grammar, punctuation, mechanism, and style and quality of expression.

\subsection{Film and streaming in education}

The concept of high culture and popular culture are considered. Furthermore, the role of film used in education. The negative effects of film and TV are also discussed.

High Culture vs Popular Culture

In this context, the concepts of high and popular are important to consider since teachers' perceptions of these concepts can influence how they regard film in general and film as teaching material.

Nilsson points out that there is no cultural theory that can provide a specific definition of what culture is. The definition of culture has to be found in the different areas of research, such as history, sociology and art. [13] Storey explains in Cultural theory and popular that there are 
many ways to describe popular culture. Films, books, and theatre that are appreciated by a large number of people are often regarded as popular culture. The second definition of popular culture includes a judgment of quality and then the question arises: Who is to decide what is good quality and what is not? [14]

Ronnberg discusses the conflict between traditional culture and popular culture and points out that adults often regard commercial visual media, such as film, TV and streaming as low culture and regard books and written texts as high culture. According to Ronnberg, it is more important to think about the thoughts that arise when children and adults, for example, watch a film, than defining the product as "high culture" or "low culture".[15]

The conclusion that culture can be used as a tool in teaching as interest media. Like as using film or streaming strategy. The lecture must make creation film to show proper identification. Because young people use technology such as the internet to access everything. The film is as a download using internet facilities.

\subsection{Film in Teaching}

There are some specific features of the film that make it a very powerful tool for teaching. Film theorist Kraucher stated, for example, that there are some aspects of reality that only the cinema is privileged to communicate. Some of the original characteristics of the film are the camera movements, angels, and editing that enable the production of views that cannot be found in reality.[16] Different visual effects are also combined with sound and music, and according to Weis and Belton, the artistic effects of film and effects on the viewer are increased by the sound. [17]

Furthermore, Lundahl discusses the use of media in English teaching in the book English Language Didactics. According to him, it is obvious that the teacher has to use all the possibilities that are offered by different media. He mentions how easy it is to find information on the internet that can be used as a base for a discussion. He also mentions the possibilities of using e-mail and chats to communicate with native speakers of English or students in other European countries. He furthermore emphasizes the possibilities of using news, documentaries, film, and music in the classroom. According to Lundahl, the line is fuzzy between high culture and popular culture and since popular culture is so important in young people's lives, the school has no longer the choice of not including it in teaching. [18]

The conclusion that film is most often used as a time-filler or for amusement. The film has some effect and element that will be nice to enjoy. Literature, film, and theatre open new worlds and communicate experience, humour, tragedy, and joy. The film project has become more important in society. It is a good recommendation if there is an obligation to include newspaper, radio, TV program and film in teaching, to enable students to learn about current events, cultural differences and different social contexts.

\section{Method}

The method in this study was an exploratory mixed method. Techniques of collecting data are documentation and questionnaire. The population of this study was all the second semester in English major ABA BSI Jakarta. There are 243 students. The sample was 40 from one of the classes. The writer collected the data was from September until December 2017.

The data collected using documentation taken from students' result test of English academic writing. The English academic writing was analyzed based on the following criteria : (1) organization (introduction, body and conclusion), (2) logical development of ideas, (3) 
grammar, (4) punctuation, spelling, and mechanics, and (5) styles and quality of expression. The paragraph was analyzed and scored by different raters and the result was compared. In other words, the final scores were taken from the average of the scores from the first and the second rater. As for the ways to analyze and score the data the raters refer to Peer Editing Checklist Rubric Brown and Barley.

To know the effectiveness of film and streaming project in English academic writing learning is taken from students' perception using questionnaire. The questionnaire consisted of 15 items that have measured about validity and reliability. To measure the validity the writer used Pearson Product Moment. While to measure reliability used Alpha Cronbach. The result of validation and reliability were all of the items in the questionnaire were valid and suitable as an instrument to measure the students' perception toward the use of film and streaming project. The writer rates themselves on 5 point Likert-scale. Likert item is useful for gathering respondents' option, feeling, habit, etc on any language-related topic. The results of the questionnaire were presented to support the topic of this study.

\section{Result}

The findings of this study showed the scores of students' English academic writing learning using film and streaming project. It is using the test. While the findings of the questionnaire were used to find out the students' perception toward the use of film and streaming project.

Students' Perception of Film and Streaming Project in English Academic Writing Learning

The result of students' perception of the film and streaming project is good. It is an effective learning and teaching process of paragraph academic writing. It shows in below chart:

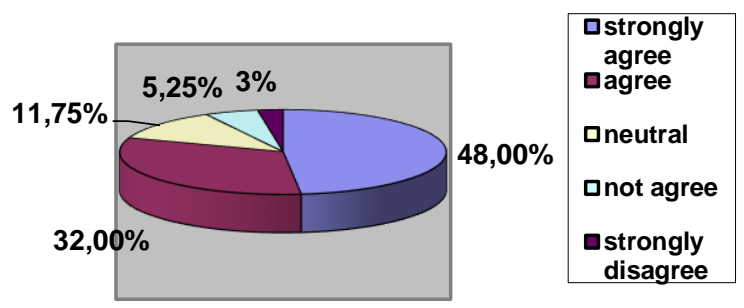

Figure 1. The percentage of students' perception toward the use of film and streaming project

Based on the data analyzed from the questionnaire above, students can feel and get the advantages of using film and streaming project in academic writing. The percentage of the answer "strongly agree" was $48 \%$, the percentage of the answer "agree" was $32 \%$, the percentage of the answer "neutral" was $11.75 \%$, the percentage of the answer "not agree" was $5.25 \%$, and the percentage of the answer "strongly disagree" was $3 \%$.

The Result of Enhancing Students' English Academic Writing Ability Using Film and Streaming Project

The result of the enhancing of students' English academic writing ability is taken from the collaborator's assessment of the students' writing and the result of pre-test and post-test.

In this study, the score was obtained from two raters who gave the score on the students' test in paragraph academic writing based on the rubric provided. In writing rubric, there are five 
components that rated by the rater. The components are 1) organizations, 2) logical development of ideas, 3) grammar, 4) punctuation, spelling and mechanism, and 5) styles and quality of expressions. The following table showed the score of the students' English academic writing from the first rater and the second rater.

Table 1. Score and percentage of Students' English academic writing from the first rater

\begin{tabular}{llll}
\hline \multicolumn{1}{c}{ Component } & \multicolumn{1}{c}{ Indicator } & Result Score & $\%$ \\
\hline Organization & $\begin{array}{l}\text { Introduction } \\
\text { Body } \\
\text { Conclusion }\end{array}$ & 2915 & $20 \%$ \\
$\begin{array}{l}\text { Logical development of ideas } \\
\text { Grammar }\end{array}$ & $\begin{array}{l}\text { Content } \\
\text { Construction are simple, } \\
\text { complex but effective } \\
\text { Syntax rules }\end{array}$ & 2820 & $19.5 \%$ \\
$\begin{array}{l}\text { Punctuation, spelling, and } \\
\text { mechanics } \\
\text { Styles and quality of expression }\end{array}$ & $\begin{array}{l}\text { Punctuation and spelling } \\
\text { Writing rules } \\
\text { Diction (word choosing) } \\
\text { Useful word, and } \\
\text { Choosing and expression, and } \\
\text { vocabulary construction. }\end{array}$ & 2921 & $219.3 \%$ \\
& & $20.1 \%$ \\
\hline
\end{tabular}

The above table showed in chart form. The following is the chart of score students' English academic writing from the first rater.
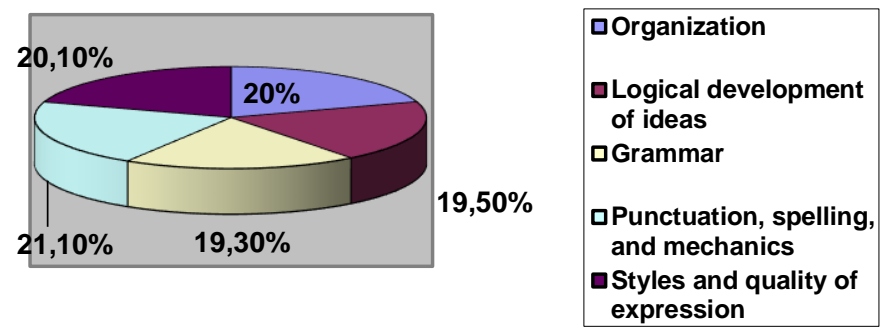

Figure 2. Score and percentage of Students' English academic writing from the first rater

The score students' English academic writing from the first rater is different from the second rater. The following is a rating from the second rater.

Table 2. Score and percentage of Students' English academic writing from the second rater

\begin{tabular}{llcc}
\hline Component & Indicator & Result Score & $\%$ \\
\hline Organization & $\begin{array}{l}\text { Introduction } \\
\text { Body }\end{array}$ & 3010 & $20.2 \%$ \\
$\begin{array}{l}\text { Conclusion } \\
\text { Grammar }\end{array}$ & $\begin{array}{l}\text { Content } \\
\text { Construction are simple, complex } \\
\text { but effective } \\
\text { Syntax rules } \\
\begin{array}{l}\text { Punctuation, } \\
\text { mechanics }\end{array}\end{array}$ & 2958 & $19.8 \%$ \\
\hline
\end{tabular}




\begin{tabular}{llcc}
\hline Component & Indicator & Result Score & $\%$ \\
\hline Styles and quality of expression & $\begin{array}{l}\text { Diction (word choosing), } \\
\text { Useful word, and } \\
\text { Choosing and expression, and } \\
\text { vocabulary construction. }\end{array}$ & 2673 & $18 \%$ \\
\hline
\end{tabular}

The above table showed in chart form. The following is the chart of score students' English academic writing from the second rater.

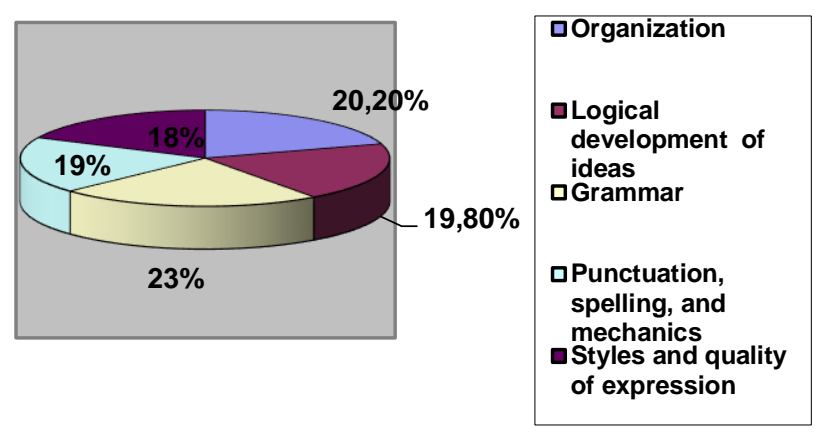

Figure 3. Score and percentage of Students' English academic writing from the second rater

Based on two tables above, they show the percentage of students' English academic writing. There are two raters that rated their writing test. There are five components in writing construction. For the first rater, in organization component shows $20 \%$. But for the second rater, there is a different percentage that is $20.2 \%$. Of course, for the second rater emphasize rating in the body. As a whole students' writing showed a good writing. Introductory of their paragraph has clear and show the relationship between a general sentence and thesis statement or main idea. Body, there is appropriate with the topic and conclusion shows a summary or main points story.

The second component is a logical development of ideas. The first rate is $19.5 \%$ and the second rate is $19.8 \%$. It is lower from the first component. Some students have difficulties when they have to develop ideas. But, it is still showing the development of ideas that are appropriate for the topic. The third component is grammar. The first rater shows $19.3 \%$ and the second rater shows $23 \%$. There are differences in the percentage of the range quite far. The fourth components are punctuation, spelling, and mechanism. The first rate is $21.1 \%$ and the second rate is $19 \%$. The last components are styles and quality of expression. The first rate is $20.1 \%$ and the second rate is $18 \%$.

From that differences, the first rater gives a high percentage of punctuation, spelling and mechanism. It followed by styles and quality of expression, then the organization is the third part. The fourth rating is logical development ideas that followed by grammar. So, it can take the conclusion that students' writing has good writing rules. But it is less in grammar. As we know that grammar is an important part of writing. The overall, students' writing showed a wellbalanced percentage of five components.

From the second table, it is the second writer showed that grammar is highest than all components. The organization is in the second rating that followed by the logical development of ideas. Then the fourth rating is punctuation, spelling and mechanism. And the lowest rating is the styles and quality of expression. From this can take concluded that in the second rater showing sequences percentage of the component. In writing, grammar has the main role. After 
that, the writer has to make a good organization with a good process of developing ideas. The next, after students, can write well in the organization, of course, it will follow with good writing rules. So, it will be easy using styles and quality of expression. The results of the pretest and posttest data analysis are as follows;

Table 3. t-Test: Paired Two Sample for Means

\begin{tabular}{lll}
\hline & Pretest & Posttest \\
\hline Mean & 77.5 & 86.45 \\
Variance & 44 & 59.07435897 \\
Observations & 40 & 40 \\
Pearson Correlation & 0.621624348 & \\
Hypothesized Mean & & \\
Difference & 0 & \\
Df & 39 & \\
t Stat & -8.984913168 & \\
P(T<=t) one-tail & $2.42155 \mathrm{E}-11$ & \\
t Critical one-tail & 1.684875122 & \\
P(T<=t) two-tail & $4.8431 \mathrm{E}-11$ & \\
t Critical two-tail & 2.02269092 & \\
\hline
\end{tabular}

The table above concluded that t-stat (8.89) > t-table (2.02), which means Ho is rejected and $\mathrm{H} 1$ accepted. It is known that English writing academic learning using an appropriate strategy. Film and streaming project gave different way in the writing process. In other words, it is able to enhance students writing ability. The pre-test scores of students have the average score is 77.5 and the post-test is 86.45 . There is the increasing about 8.95 . So, the results of the study shown a significant difference were found in the academic writing learning in favour of the students who studied using film and streaming project. This strategy gives unique and fun learning. The students can develop their imagination. Film and streaming project are different strategies for English academic writing learning because it has complete features to attract students' desire in learning with technology supporting for nowadays. Moreover, writing is part of the difficult skill in learning. Using this strategy, the learning process offers a different way.

\section{Discussion}

Based on the finding above, it can be interpreted that the second semester English major of ABA BSI Jakarta in the mastery of academic paragraph writing has a weakness. There are two perceptions, the first from the first rater that the weakness is grammar and logical development of ideas. From the second rater are style and quality of expression. All of whole, students' mastery in writing was weak in styles and development of ideas. on the other hand, in their writing has shown a good paragraph based on the writing rubric. According to Oshima and Hogue say that there are two other structural parts, coherence and unity. Hogue explains that a paragraph should consist of three items. First, the topic sentence, tell what topic the paragraph is going to discuss. Second, the supporting sentence gives details about the topic. Third, the concluding sentence summarizes the main points and perhaps makes a final comment. [19] Like as the result of students' writing has related to this theory. They write a paragraph that has been caring with writing rules. how about it is complete with five components writing construction.

The first time using film and streaming project in academic writing teaching and learning process, the students have a good appreciate. They enjoy watching the film and is an enjoyable 
way to learn. Because it shows a nice condition and fun. It is audiovisual media as a good complement to written texts. During this time, the students just learn theory after that doing assignment. Of course, it gives a bored feeling. But using film and streaming project, they can get more idea and develop supporting in their writing. They have many stories from the film's story. They can develop positive and negative values of film to be a good story in writing. Not only that, they also get many new vocabularies.

The students are generally also very good at participating in writing discussing after watching a film, like as when we have to choose an idea for writing. Thus, film and streaming project is an easy way of learning at the same time and very efficient. The real action in the class is an integrated film in large projects, such as the lecture gives a novel to understanding for group work. After that, they have to make a short film and they are a player. They can modify the novel's story. The other group can make writing after watching the film. When the lecture used this project, it gives nice condition in learning. Because the use of film was to find a link between school and the life of the students out of school.

Of course, there are so many different ways to work with film in English writing teaching. It believes that the students can learn very much from looking at film. They can improve their receptive skills by listening and by reading the English subtitle. They also increased their vocabulary. Subtitle in the film can give new vocabulary. It has given proof, like as in Peters, et.al research that has studied vocabulary through the audiovisual input, it is the differential effect of L1 subtitles and captions. [20] After they watched the film, they also improve their communicative skills as they talk about a common experience with their classmate. They can share and learn about cultural differences and get a different perspective of their experience. Then, they can write about what they get in discussion to be a good writer. Using film and streaming project is not only part of the project. But it is as part of exploring their life that applies in writing. The lecture can explore this strategy not only just in writing learning but also in other language skill. It can combine with other strategy or media.

\section{CONCLUSION}

Based on the findings, it shows that the students' academic writing of the second-semester students which measured by criteria in writing rubric with five components was $78 \%$ of the students were able to write a good paragraph. The comparison of the two raters showed a good sequence in percentage. The higher percentage from the first rater is punctuation, spelling and mechanism, and the second rater is grammar. It means that the students were able to write a good paragraph but the weakness of students' writing could be seen from the lower percentage. The lower percentage from the first rater is grammar and the second rater is style and quality of expression.

The result of the questionnaire showed students' perception toward the used film and streaming project. It was found the most students to learn writing through film and streaming project. It showed from $100 \%$ the resulting score that the writer expected $48 \%$ of students' answer strongly agree, $32 \%$ of students answer agree, $11.75 \%$ of students answer neutral, $5.25 \%$ of students answer not agree, and $3 \%$ of students answer strongly disagree. From this data, it can conclude that the students' perception toward film and streaming project was very strong. It means that they were interested to learn writing through film and streaming project and give a positive context in learning. This project gives advantages to improve students' writing and shows different learning strategies without bored feeling. There is the significant influence from 
film and streaming project in English academic writing. The students have increased their academic writing score.

\section{References}

[1] Heaton, J.B, Writing English Language Test. London: Longman, 1999, p.135

[2] Harmer, J. How to teach writing. 2004. Retrieved from http:/respository.upi.edu/operator/upload/t_bing_0604416_chapter1.pdf. on 5 January 12012

[3] Bradbury, K.S.,"Teaching Writing in the Context of a National Digital Literacy Narrative," $\begin{array}{llll}\text { Computer and } \quad \text { Composition, } & \text { Vol.32, 2018, } & \text { p.54-70. }\end{array}$ https://doi.org/10.1016/J.COMPCOM.2014.04.003

[4] Bonsignori, V., "Using films and TV series for ESP teaching: A multimodal perspective," System, 2014, https://doi.org/10.1016/J.SYSTEM.2018.01.005

[5] Frumuselu, A.D., De Maeyer, Sven., Donche, Vincent., Colom Plama, Maria del Mar Gutierrez., "Television series inside the EFL classroom: Bridging the gap between teaching and learning informal language through subtitles," Linguistics and Education, Vol.32, 2015, pp.107-117

[6] Iltera, Binnur Genç, "How does technology affect language learning process at an early age?" GlobELT: An International Conference on Teaching and Learning English as an Additional Language, Procedia - Social and Behavioral Sciences, No. 199, 2015, pp. $311-316$

[7] Chaudran, C, Second Language Classrooms: Research on Teaching and Learning. Cambridge: Cambridge University Press, 1995, p.87

[8] Weigle, Sara Cushing, Assessing Writing. United Kingdom: Cambridge, p.19

[9] Nation, I.S.P, Teaching ESL/EFL Reading and Writing. New York \& London: Routledge, 2009, p.113

[10] Brown, Douglas. Teaching by Principles An Interactive Approach to Language Pedagogy Second Editio. California: Longman, 2000, p.335

[11] Linse, Caroline T. Practical English Language Teaching Young Learner. McGraw Hill, 2005, p.98

[12] Brown, Douglas, Language Assessment Principles and Classroom Practices. San Francisco, California: Longman, 2003

[13] Nilsson, S. Kulturens vagar: Kultur och kulturpolitik I Sverige. Malmo: Plyvalent, 1999, p.10

[14] Storey, J. Cultural Theory and Popular Culture: a Reader $3^{\text {rd }}$ ed. London: Prentice Hall, 2006

[15] Ronnberg, M. "nya medier" - men samma Gamla barnkultur? Om det tredje konets lek, larande och motstand via TV, video och datorpel. Uppsala: Filmforlaget. 2006

[16] Kaucher, S. Theory of Film: The Redemption of Physical Reality. New York: Oxford University Press, 1973

[17] Weis, E \& Belton, J. Introduction. In Weis, E \& Belton, J (eds), Film sound: theory and practice. New York: Colombia University Press, 1985, pp.1-12

[18] Lundahl, B. English Sprakdidaktik. Lund: Student literature, 2009

[19] Oshima, Alice \& Hogue, A. Writing academic English ( $3^{\text {rd }}$ ed.). New York, NY:Adison- Wesley Longman, 1999, p.4

[20] Peters, Elke, Heynen, Eva, Puimege, Eva, "Learning Vocabulary through audiovisual input: The differential effect of L1 subtitile and captions, System, Vol.63, 2016, pp.134-148 
Appendix QUESTIONNAIRE

Read the following statements and check $(\sqrt{ })$ according to your perception of using film and streaming project in an academic writing class.
SA : Strongly Agree
$\mathrm{N} \quad$ : Neutral
A : Agree
SDA : Strongly Disagree
NA : Not Agree

\begin{tabular}{|c|c|c|c|c|c|c|}
\hline No & Statements & SA & $\mathrm{A}$ & $\mathrm{N}$ & NA & SDA \\
\hline 1. & Ideas for using film and streaming project in writing class is good & & & & & \\
\hline 2. & I feel enjoy when I did assignment writing using this project. & & & & & \\
\hline 3. & $\begin{array}{l}\text { I can access the internet anywhere (ex: at home, on campus, in the } \\
\text { restaurant, etc). }\end{array}$ & & & & & \\
\hline 4. & $\begin{array}{l}\text { I can use film and streaming project as one of learning medium, } \\
\text { especially in writing. }\end{array}$ & & & & & \\
\hline 5. & Film and streaming project give more idea in writing & & & & & \\
\hline 6. & I can find many values from film to support the idea. & & & & & \\
\hline 7. & Film and streaming project is interested in writing learning & & & & & \\
\hline 8. & I can build the story from the film. & & & & & \\
\hline 9. & I do not feel bored when I write after watching the film. & & & & & \\
\hline 10. & I know how to develop supporting sentence & & & & & \\
\hline 11. & I can improve my idea. & & & & & \\
\hline 12. & I can get a more new vocabulary. & & & & & \\
\hline 13. & The film gives me positive values in writing. & & & & & \\
\hline 14. & $\begin{array}{l}\text { I can filter the bad effect of Film and streaming project to be a } \\
\text { good story in writing. }\end{array}$ & & & & & \\
\hline 15. & The condition of learning is fun. & & & & & \\
\hline
\end{tabular}

